\title{
Impact of different dietary protein sources on performance, litter quality and foot pad dermatitis in broilers
}

\author{
A. Abd El-Wahab ${ }^{1,2}$, C. Visscher ${ }^{1,3}$ and J. Kamphues ${ }^{1}$ \\ 1 University of Veterinary Medicine Hannover, Foundation, Institute for Animal Nutrition, D-30173 Hanover, Germany \\ ${ }^{2}$ Mansoura University, Faculty of Veterinary Medicine, Department of Nutrition and Nutritional Deficiency Diseases, \\ 35516 Mansoura, Egypt
}

KEY WORDS: protein sources, performance, litter quality, foot pad dermatitis, broilers

Received: 3 August 2017

Revised: 28 February 2018

Accepted: 10 June 2018

${ }^{3}$ Corresponding author:

e-mail: christian.visscher@tiho-hannover.de

\begin{abstract}
The aim of this study was to evaluate potential influences of different dietary protein sources on performance, litter quality and health of foot pads in broilers. In total, 160 one-day-old chickens were divided into four dietary groups at day 8. Four different diets were prepared as follows: the level of soyabean meal in the control diet amounted $32.5 \%$ (SBM), while in other diets soyabean meal was partly replaced by rapeseed meal 14.5\% (RSM); haemoglobin meal 4.5\% (HBM) or algae meal 4.0\% (ALG). Body weight was measured weekly. Measurement of dry matter content of litter and excreta as well as external assessment of foot pads were performed weekly. Birds fed the RSM diet had the highest body weight at day 44 in comparison to animals fed other experimental diets. Broilers fed the HBM diet had the lowest body weight at the end of the trials. Foot pad dermatitis (FPD) severity was significantly higher in birds fed RSM and ALG diets in comparison with those fed SBM or HBM diets at day 44 of life. In conclusion, using RSM could be the most suitable alternative protein source due to higher body weight gains. However, further studies are required to optimize the diet composition which could simultaneously improve foot pad health.
\end{abstract}

\section{Introduction}

World demand for protein is rising in line with the growing human population. According to Food and Agriculture Organization of the United Nations (FAO, 2013) the global food demand of 2013 will double in 2050, particularly for animal protein (meat and dairy products). In poultry nutrition, due to high protein accretion, there is a need to supplement this substance because it plays essential roles in the body and is needed for growth. The amino acids requirements for broilers are high, especially during the early stages of life (Beski et al., 2015). Soyabean meal (SBM) is the dominant protein source used in poultry diets due to its favourable nutrient composition and its well-balanced amino acids profile. It is also an excellent source of energy not only for poultry but also for swine. Thus, the high protein content, with its well-balanced and highly digestible amino acids, makes SBM a valuable protein for human nutrition and animal feeding (Kocher et al., 2002).

There are market trends towards the use of cheaper raw materials, protein sources of higher sustainability, and products increasing animal health characteristics (Laudadio and Tufarelli, 2011; van der Spiegel et al., 2013). Soyabean meal is the gold standard to which alternative protein sources are compared. Some important aspects for using, alternative protein sources for livestock nutrition should be considered. Among them are performance and health of animals 
as well as food safety that should not be adversely affected.

Rapeseed meal (RSM) has been used as a feed ingredient worldwide for many years in such animal species as poultry, swine, cattle and fish (Nagel et al., 2012). According to FAO (2016) the world RSM production amounted 39.1 million tonnes in 2015/2016, and in 2014 the main producer of RSM was the European Union (13.9 million tonnes). The amino acid balance of RSM compares well with that of SBM (Clandinin, 1967), the former being higher in methionine and the latter in lysine. Blood meal, an important animal protein by-product, contains over $800 \mathrm{~g}$ protein $\cdot \mathrm{kg}^{-1}$ dry matter (DM), $90 \mathrm{~g}$ total lysine $\cdot \mathrm{kg}^{-1} \mathrm{DM}$ and small amounts of ash and lipids (Donkoh et al., 2001).

In poultry diets, dried algae up to a level of $5-10 \%$ can be used as partial replacement for conventional proteins (Becker, 2004). The yellow colour of broiler skin, shanks and egg yolk is an interesting effect of feeding algae (important for some regional markets in the world) (Becker, 2004; Pulz and Gross, 2004). Chemical composition of algae is well documented. They mainly contain proteins (28-71\% DM), carbohydrates (10-57\% DM), lipids (4-22\% DM), vitamins, trace elements and antioxidants (Becker, 2004; Yaakob et al., 2014). Howev$\mathrm{er}$, the nutritive value of microalgae is determined mainly by the protein content. Also, highly unsaturated fatty acids (e.g., eicosapentaenoic acid, arachidonic acid and docosahexaenoic acid) content is essential (Spolaore et al., 2006). It was estimated that Chlorella and Spirulina algae are the most popular in the market (Pulz and Gross, 2004).

Litter quality is considered to be a major factor in the development of foot pad dermatitis (FPD) along with nutrition (Kamphues et al., 2011; Taherparvar et al., 2016). Various dietary nutrients/ingredients can affect the litter quality and hence the foot pad health. The indigestible carbohydrate levels in plant sources (primarily SBM) are remarkably high, about 15-20\% DM (Choct, 1997; Choct et al., 2010). These carbohydrates are known as non-starchpolysaccharides (NSP) and are also found at high concentrations in wheat and other grains affecting the digestive process and litter quality (Choct, 1997; Youssef et al., 2011). The higher dietary NSP concentrations the higher viscosity of digesta which results in 'sticky' excreta adhering to bird foot pads (Youssef et al., 2011). Moreover, SBM is known for its high potassium content $\left(>20 \mathrm{~g} \cdot \mathrm{kg}^{-1} \mathrm{DM}\right)$, which leads to an increase in water intake and moisture of excreta (Youssef et al., 2011).
FPD poses a challenge for poultry production, potential effects on productivity, animal welfare and economics (Abd El-Wahab et al., 2011, 2012a). FPD is affected by several factors; among them are litter quality, diet composition and intestinal diseases (Abd El-Wahab et al., 2011, 2012a, 2012b, 2013a, 2013b; Youssef et al., 2011). The foot pad lesions may be painful, particularly in severe cases, and together with a worsening state of an animal constitute a serious problem. Also, through the lesions bacteria or other pathogens can get into animal organism and as a result cause partial or total condemnation of the carcass (Ekstrand et al., 1997). Nevertheless, feeding measures and housing conditions are as important as managing the quality of litter, especially its moisture content (the key factor) in reducing the incidence and severity of FPD.

The aim of the present study was to evaluate the potential effects of different dietary protein sources and levels on performance, litter quality and health of foot pads in broilers.

\section{Material and methods}

Animal experiments were carried out according to German regulations. A notification or an approval according to the Animal Protection Act were not needed to perform the experiments.

\section{Animals and housing}

In total, 160 one-day-old chickens (ROSS-708, as-hatched) were obtained from a commercial hatchery. Before starting the feeding trials at day 8 , all birds were housed in four identical floor pens littered with wood shavings that were kept very dry and clean to prevent any foot pad lesions, especially during the first week of age. Birds were fed a commercial pelleted starter diet (Deuka, Deutsche Tiernahrung Cremer GmbH \& Co. KG, Düsseldorf, Germany) ad libitum that covered birds requirements. A temperature of $34-36{ }^{\circ} \mathrm{C}$ at the first day of age was ensured by infrared lamps and was lowered by $1{ }^{\circ} \mathrm{C}$ every two days. The photoperiod from day 4 was $16 \mathrm{~h}$ of light and $8 \mathrm{~h}$ of darkness.

\section{Experimental design}

At the beginning of the second week, animals were randomly allocated to four groups with two replicate pens of 20 birds each. All animals were wingtagged. All eight pens were identical in size $(2 \times 1 \mathrm{~m})$, littered with wood shavings $\left(1 \mathrm{~kg} \cdot \mathrm{m}^{-2} ; 88.3 \pm 0.2 \%\right.$ $\mathrm{DM})$. Four different diets were prepared for this experiment. The level of soyabean meal (SBM) in the 
Table 1. Chemical composition of starter and experimental diets fed to broilers, $\%$

\begin{tabular}{|c|c|c|c|c|c|}
\hline \multirow{2}{*}{ Indices, \% } & \multirow{2}{*}{$\begin{array}{l}\begin{array}{l}\text { Starter } \\
\text { (days 0-7) }\end{array} \\
\text { all groups }\end{array}$} & \multicolumn{4}{|c|}{ Treatment (days 8-44) ${ }^{1}$} \\
\hline & & SBM & RSM & HBM & ALG \\
\hline Wheat & + & 48.9 & 40.5 & 34.6 & 38.6 \\
\hline Maize & + & 9.00 & 12.5 & 28.4 & 19.8 \\
\hline Soyabean meal & + & 32.5 & 22.9 & 22.5 & 28.0 \\
\hline Rapeseed meal & - & - & 14.5 & - & - \\
\hline Haemoglobin meal & - & - & - & 4.50 & - \\
\hline Algae meal & - & - & - & - & 4.00 \\
\hline Fat/oil & + & 5.20 & 5.20 & 5.20 & 5.20 \\
\hline $\mathrm{CaCO}_{3}$ & + & 1.80 & 1.80 & 1.80 & 1.80 \\
\hline Dicalcium phosphate & - & 1.00 & 1.00 & 1.37 & 1.00 \\
\hline Sodium chloride & + & 0.35 & 0.35 & 0.35 & 0.35 \\
\hline Lysine & - & 0.27 & 0.25 & 0.20 & 0.28 \\
\hline Methionine & + & 0.16 & 0.15 & 0.19 & 0.15 \\
\hline Threonine & - & 0.10 & 0.10 & 0.10 & 0.10 \\
\hline $\begin{array}{l}\text { Trace elements } \\
\text { supplement }^{2}\end{array}$ & + & 0.30 & 0.30 & 0.30 & 0.30 \\
\hline Vitamin supplement $^{3}$ & + & 0.30 & 0.30 & 0.30 & 0.30 \\
\hline \multicolumn{6}{|c|}{$\begin{array}{l}{ }^{1} \text { treatment: SBM - diet with only soyabean meal, RSM - diet with } \\
\text { rapeseed meal, HBM - diet with haemoglobin meal, ALG - diet with } \\
\text { algae meal; }{ }^{2} \text { added to the diet per kg: mg: Cu } 22.5, \mathrm{Zn} 150, \mathrm{I} \text {, } 1.50 \text {, } \\
\text { Se } 0.45 ;{ }^{3} \text { added to the diet per kg: IU: vit. A } 12,000 \text {, vit } D_{3} 5000 ; \mathrm{mg}: \\
\text { vit. E } 25 ; \mu \text { : biotin } 200 \text {; due to statistical approximation the sum of } \\
\text { diets might not be } 100 \%\end{array}$} \\
\hline
\end{tabular}

control diet amounted $32.5 \%$, while in other diets SBM was partly replaced by rapeseed meal (RSM) $14.5 \%$; haemoglobin meal (HBM) $-4.5 \%$; or algae meal (ALG) $-4 \%$ (Table 1). It has to be stressed that the phytase, NSP-enzymes and anticoccidial drugs were not used in all experimental diets. The diets were offered in circular troughs and water was in bell drinkers. Both were available ad libitum. Samples of the four diets were analysed by standardised laboratory methods (VDLUFA, 2012). The composition and the chemical analysis of the experimental diets are shown in Tables 1 and 2, respectively.

\section{Performance parameters}

Feed and water intakes were measured daily at pen level. Individual body weight (BW) of the animals was recorded weekly. The feed conversion ratio (FCR) was calculated on the basis of feed consumed throughout the experimental period.

\section{Excreta and litter quality}

The fresh excreta were collected from each pen once a week by putting a pond liner in each pen for one hour until about 70-100 g of fresh pure excreta per pen had been obtained. The collected excreta (sampling during $\sim 1 \mathrm{~h}$ ) were then removed from each pen, thoroughly mixed and dried at $103^{\circ} \mathrm{C}$ to determine the DM content.
Litter samples for measuring DM content were collected weekly from five sites (the four corners and the middle of the pen), then thoroughly mixed. Subsamples of about $100 \mathrm{~g}$ were taken to assess moisture content by drying at $103{ }^{\circ} \mathrm{C}$ until a constant mass was obtained (VDLUFA, 2012).

\section{FPD scoring criteria}

The external scoring was performed for birds at the beginning of the experiment (day 8), then weekly till day 44 . If the feet were dirty they were gently washed with a wet cloth and dried before scoring; only the central plantar area was scored. Signs of foot pad lesions were recorded on a 7-point scale $(0=$ normal skin; $7=$ over half of the foot pad is covered with necrotic scales) according to Mayne et al. (2007).

\section{Statistical analysis}

The statistical analysis of the collected data was performed using the Statistical Analysis System for Windows, the SAS ${ }^{\circledR}$ Enterprise Guide ${ }^{\circledR}$ version 7.1 (SAS Institute Inc., Cary, NC, USA). The collected data (individual performance data as well as foot pad scores) were analysed by means of one-factorial analysis of variance for normally distributed data with the individual as the replicate. Results of $P<0.05$ were treated as statistically significant. However, it has to be pointed out that feed and water intakes, FCR, as well as DM content in excreta and litter were estimated only on pen level, and therefore could not be statistically analysed due to the low number.

\section{Results}

\section{Chemical analyses of diets}

Chemical analyses of the different experimental diets are shown in Table 2. The results indicated similar energy content $\left(13.4-14.1 \mathrm{MJ} \cdot \mathrm{kg}^{-1} \mathrm{DM}\right)$ and protein content $\left(228-235 \mathrm{~g} \cdot \mathrm{kg}^{-1} \mathrm{DM}\right)$ for all experimental diets (days 8-44). However, there was a decrease in the potassium level in the HBM diet (7.66 $\mathrm{g} \cdot \mathrm{kg}^{-1} \mathrm{DM}$ vs $9.83 \mathrm{~g} \cdot \mathrm{kg}^{-1} \mathrm{DM}$ for the SBM diet). No marked differences in the sodium content were observed between the experimental diets $\left(1.95-2.13 \mathrm{~g} \cdot \mathrm{kg}^{-1} \mathrm{DM}\right)$.

\section{Feed intake and performance}

At the beginning of the experiment (day 8), no significant differences in BW were noted between the experimental groups (birds were randomly distributed to the pens). It should be stressed that 
Table 2. Chemical analyses of all diets fed to broilers

\begin{tabular}{|c|c|c|c|c|c|}
\hline \multirow{2}{*}{ Indices } & \multirow{2}{*}{$\begin{array}{l}\begin{array}{l}\text { Starter } \\
\text { (days 0-7) }\end{array} \\
\text { all groups }\end{array}$} & \multicolumn{4}{|c|}{ Treatment (days 8-44) $)^{1}$} \\
\hline & & SBM & RSM & HBM & ALG \\
\hline \multicolumn{6}{|c|}{ Chemical analyses, $\mathrm{g} \cdot \mathrm{kg}^{-1} \mathrm{DM}$} \\
\hline crude ash & 59.6 & 64.8 & 69.2 & 63.3 & 65.5 \\
\hline crude fat & 59.1 & 80.1 & 84.5 & 83.3 & 89.6 \\
\hline crude fibre & 21.8 & 40.2 & 46.7 & 30.4 & 35.1 \\
\hline crude protein & 252 & 231 & 228 & 235 & 235 \\
\hline starch & 404 & 386 & 368 & 422 & 402 \\
\hline sugar & 59.1 & 51.8 & 62.4 & 39.2 & 45.6 \\
\hline $\mathrm{Ca}$ & 10.8 & 14.0 & 14.7 & 15.7 & 14.4 \\
\hline$P$ & 7.84 & 5.05 & 7.16 & 6.79 & 6.77 \\
\hline K & 11.0 & 9.83 & 8.93 & 7.66 & 9.31 \\
\hline $\mathrm{Na}$ & 1.53 & 1.95 & 2.13 & 1.97 & 1.96 \\
\hline $\mathrm{Cl}$ & 1.98 & 4.18 & 4.09 & 3.99 & 4.14 \\
\hline arginine & 15.1 & 15.0 & 14.4 & 13.0 & 14.7 \\
\hline cysteine & 5.44 & 4.31 & 4.28 & 3.87 & 4.16 \\
\hline lysine & 16.4 & 14.1 & 13.8 & 15.4 & 14.1 \\
\hline methionine & 4.32 & 5.23 & 5.19 & 4.97 & 5.74 \\
\hline phenylalanine & 12.6 & 10.6 & 10.9 & 12.3 & 11.1 \\
\hline threonine & 10.4 & 8.63 & 8.93 & 8.01 & 8.84 \\
\hline valine & 10.2 & 9.97 & 10.5 & 12.4 & 10.8 \\
\hline glycine & 10.6 & 9.53 & 10.1 & 9.80 & 9.81 \\
\hline serine & 13.1 & 11.3 & 11.3 & 10.9 & 11.3 \\
\hline tyrosine & 8.75 & 7.62 & 7.52 & 7.10 & 7.69 \\
\hline $\begin{array}{l}\text { Metabolizable energy, } \\
\mathrm{MJ} \cdot \mathrm{kg}^{-1} \mathrm{DM}\end{array}$ & 13.2 & 13.5 & 13.4 & 14.1 & 14.0 \\
\hline
\end{tabular}

the total feed intake was corrected for mortality (Table 3). Birds fed the RSM diet had a markedly higher feed intake (4 $656 \mathrm{~g})$ than other experimental groups. However, birds fed the HBM diet had the numerically lowest feed intake (3859 g). Regarding the total water intake, birds fed the RSM diet had a numerically higher total water intake (11 $616 \mathrm{~g})$

Table 3. Feed and water intakes and growth performance of broilers fed diets with different protein sources and combinations

\begin{tabular}{|c|c|c|c|c|}
\hline \multirow{2}{*}{ Indices } & \multicolumn{4}{|c|}{ Treatment $^{1}$} \\
\hline & SBM & RSM & HBM & ALG \\
\hline $\begin{array}{l}\text { Total feed intake } \\
\text { (days 8-44), } \\
\mathrm{g} \cdot \text { bird }^{-1}\end{array}$ & 4368 & 4656 & 3859 & 4196 \\
\hline \multicolumn{2}{|c|}{$\begin{array}{l}\text { Total water intake, } 11048 \\
\text { (days } 8-44 \text { ), } \\
\mathrm{g} \cdot \text { bird }^{-1}\end{array}$} & 11616 & 9796 & 11196 \\
\hline $\begin{array}{l}\text { Water : feed intake } \\
\text { (days 8-44) }\end{array}$ & 2.53 & 2.49 & 2.53 & 2.68 \\
\hline
\end{tabular}

Body weight $\quad 180.7 \pm 14 \quad 184.3 \pm 11.3182 .4 \pm 12.1 \quad 180.4 \pm 15.7$ (day 7), g

Body weight $\quad 2769 \pm 319^{\mathrm{b}} 2909 \pm 325^{\mathrm{a}} 2478 \pm 320^{c} \quad 2739 \pm 378^{\mathrm{b}}$ (day 44), $g$

$\begin{array}{lllll}\text { FCR (days 8-44) } & 1.68 & 1.71 & 1.68 & 1.64\end{array}$

${ }^{1}$ see Table 1; abc - means within the same row with different superscripts are significantly different at $P<0.05$ than other groups, while birds fed HBM had a very low total water intake (9 $796 \mathrm{~g}$ ). The water:feed intake ratio was numerically higher for groups fed the ALG diet (2.68), while the numerically lowest ratio was recorded in groups fed the RSM diet (2.49). The water:feed intake ratio was similar between groups fed SBM and HBM diets (2.53).

Significant differences were observed in the final BW between the experimental groups (Table 3). Birds fed the RSM diet had a significantly higher BW (2 $909 \mathrm{~g}$ ) in comparison to other experimental groups. No significant differences in the final BW (day 44) were noted between groups fed ALG and SBM diets (2 739 and $2769 \mathrm{~g}$, respectively). Birds fed the HBM diet had a significantly the lowest BW (2 $478 \mathrm{~g})$.

Furthermore, the FCR was almost equal between groups fed SBM and RSM diets (68 and 71, respectively), while the numerically most favourable FCR was recorded for groups fed the ALG diet (64).

\section{Excreta and litter quality}

The numerically highest mean DM content for excreta was found in birds fed the RSM diet (16.4\%), while the lowest mean DM content for excreta was noted in those fed the ALG diet (14.7\%) (Table 4). No marked differences were found between groups fed the HBM and SBM diets (15.3 and 15.6\%, respectively).

Regarding litter DM contents, birds fed the HBM diet had the numerically highest mean DM content (51.1\%) (Table 4). The lowest mean DM content was noted in birds fed the SBM diet (41.8\%). However, no marked differences were observed between birds fed the RSM and ALG diets (45.6 and 46.8\%, respectively). Again, birds fed the SBM diet had numerically the lowest final litter DM content (44.8\%).

\section{FPD lesions}

At the beginning of the experiment (day 8) there was no evidence of external FPD lesions. Birds fed either RSM or ALG diets had significantly $(P<0.05)$ the highest FPD scores $(6.28$ and 6.58, respectively) at day 44 (6 week) of life (Table 5). No significant differences in FPD scores were found between birds fed either SBM or HBM diets (5.42 and 5.48, respectively) at day 44 of life. To give an idea regarding clinical relevance, the prevalence of high/severe FPD scores (6-7) amounted to 76 and $88 \%$ for birds fed RSM and ALG diets vs 46 and $56 \%$ for those fed SBM and HBM diets, respectively. 
Table 4. Dry matter (DM) contents of excreta and litter in broilers fed diets with different protein sources and combinations, \%

\begin{tabular}{|c|c|c|c|c|c|}
\hline \multirow{2}{*}{\multicolumn{2}{|c|}{ Indices }} & \multicolumn{4}{|l|}{ Treatment $^{1}$} \\
\hline & & SBM & RSM & HBM & ALG \\
\hline \multicolumn{6}{|c|}{ DM contents of excreta, \% } \\
\hline \multirow{5}{*}{ week } & & 14.2 & 14.9 & 15.1 & 13.1 \\
\hline & 3 & 13.9 & 16.5 & 15.6 & 14.9 \\
\hline & 4 & 15.5 & 15.2 & 12.9 & 13.2 \\
\hline & 5 & 16.2 & 15.9 & 14.7 & 14.9 \\
\hline & 6 & 18.3 & 19.3 & 18.2 & 17.3 \\
\hline \multicolumn{2}{|c|}{ mean \pm SD } & $15.6 \pm 1.76$ & $16.4 \pm 1.75$ & $15.3 \pm 1.91$ & $14.7 \pm 1.71$ \\
\hline \multicolumn{6}{|c|}{ DM contents of litter, $\%$} \\
\hline \multicolumn{2}{|c|}{ week 2} & 55.9 & 58.8 & 69.2 & 59.2 \\
\hline & 3 & 42.8 & 45.3 & 58.1 & 49.1 \\
\hline & 4 & 37.3 & 38.4 & 44.9 & 40.4 \\
\hline & 5 & 34.7 & 39.2 & 41.9 & 39.0 \\
\hline & 6 & 38.4 & 47.7 & 41.4 & 46.6 \\
\hline mean $=$ & $\pm \mathrm{SD}$ & $41.8 \pm 8.39$ & $45.8 \pm 8.23$ & $51.1 \pm 12.2$ & $46.8 \pm 8.07$ \\
\hline Final litter & $\mathrm{DM}^{2}$ & 44.8 & 46.6 & 46.5 & 47.9 \\
\hline
\end{tabular}

${ }^{1}$ see Table $1 ;{ }^{2}$ whole litter material (wood shavings, excreta, feathers) at the end of the experiment; SD - standard deviation

Table 5. Development of external foot pad scores of broilers fed diets with different protein sources and combinations

\begin{tabular}{rllll}
\hline \multirow{2}{*}{$\begin{array}{l}\text { Food pad Treatment } \\
\text { score }\end{array}$} & SBM & RSM & HBM & ALG \\
\hline week 2 & $0.95 \pm 0.508^{\mathrm{a}}$ & $1.25 \pm 0.479^{\mathrm{a}}$ & $0.80 \pm 0.410^{\mathrm{a}}$ & $0.60 \pm 0.398^{\mathrm{a}}$ \\
3 & $2.00 \pm 0.934^{\mathrm{a}}$ & $2.95 \pm 1.10^{\mathrm{a}}$ & $1.55 \pm 0.564^{\mathrm{b}}$ & $2.15 \pm 1.10^{\mathrm{a}}$ \\
4 & $3.35 \pm 0.98^{\mathrm{b}}$ & $4.20 \pm 1.15^{\mathrm{a}}$ & $2.85 \pm 1.21^{\mathrm{c}}$ & $3.90 \pm 0.913^{\mathrm{b}}$ \\
5 & $4.40 \pm 1.02^{\mathrm{b}}$ & $5.25 \pm 1.06^{\mathrm{a}}$ & $4.00 \pm 1.22^{\mathrm{c}}$ & $4.90 \pm 1.02^{\mathrm{b}}$ \\
6 & $5.42 \pm 1.21^{\mathrm{b}}$ & $6.28 \pm 1.02^{\mathrm{a}}$ & $5.48 \pm 1.54^{\mathrm{b}}$ & $6.58 \pm 0.01^{\mathrm{a}}$ \\
\hline
\end{tabular}

${ }^{1}$ see Table 1; abc - means within the same row with different superscripts are significantly different at $P<0.05$

\section{Discussion}

In this study, parts of the soyabean meal (32.5\% in group SBM) were replaced by rapeseed meal (RSM: $22.9 \%$ soyabean meal and $14.5 \%$ rapeseed meal), haemoglobin meal (HBM: 22.5\% soyabean meal and $4.5 \%$ haemoglobin meal) or algae meal (ALG: $28.0 \%$ soyabean meal and $4.0 \%$ algae meal).

It is well known that feed intake depends not only on dietary energy content, but also on protein quality, which can be attributed to the perfect amino acid balance justifying the use of ideal protein concept (Nahashon et al., 2006; Tufarelli et al., 2007). The birds fed the RSM diet had the numerically highest absolute feed intake in this study. Nonetheless, this was not consistent with that reported by Kermanshahi and Abbasi Pour (2006) who found in a study on broiler chickens that adding 150 and $300 \mathrm{~g} \cdot \mathrm{kg}^{-1}$ of RSM to diets had a negative effect on feed intake. However, Kölln et al. (2014) reported that replacing SBM with up to $20 \% \mathrm{RSM}$ led to a markedly higher feed intake in broilers (3 $254 \mathrm{~g}$ vs $2802 \mathrm{~g}$ ). These contradictory results might be caused by the presence of different varieties of RSM and hence their qualities used in those studies (Zeb, 1998). In the ALG group, however, the feed intake was not different from that of the SBM group. Nevertheless, in the algae group there was a continuously higher water:feed intake ratio.

Regarding growth performance, no significant differences were found in the final $\mathrm{BW}$ between groups fed the SBM or ALG diets. It is well known that algae have a high protein quantity, these proteins being of high quality and comparable to conventional vegetable proteins (Becker, 2007). Similarly, in this study almost identical protein contents and amino acids levels were noted for both SBM and ALG diets. These results are also in agreement with those obtained by Evans et al. (2015) who concluded that diets containing $0,6,11$ and $16 \%$ algae were statistically similar in performance to broilers fed SBM. However, at a higher inclusion rate of $21 \%$ algae diet there was a decrease in the performance and amino acid digestibility rate. The authors speculate that this may have been caused by the same process that increased firmness. Protein gelation during pelleting may have increased the viscosity of digesta, preventing endogenous enzymes gaining access to substrates in the digesta, thus decreasing performance and amino acid digestibility (Evans et al., 2015).

Kölln et al. (2014) found that replacing SBM with RSM up to $20 \%$ led to significantly higher BW in broilers (2 407 vs $2106 \mathrm{~g}$ ). It is an obvious relationship between feed intake and final body weight. Nevertheless, it was reported that including whole rapeseed and rapeseed meal at the 5, 10 or $15 \%$ levels linearly led to reduced performance (Toghyani et al., 2009). Commenting on these and similar discrepancies, two possible explanations are suggested: firstly, differences in the nutritional quality of the non-RSM part of the diet and secondly, differences in the chemical characteristics of the RSM used in the various experiments (March and Biely, 1971).

The significantly lower BW of the group fed the HBM diet in this study is supported by the findings of Khawaja et al. (2007) who reported that blood meal can be effectively used up to $3 \%$ only without having any adverse effects on broiler growth. Nevertheless, there are some reports indicating that adding 1 to $4 \%$ blood meal to diets can improve poultry performance (Donkoh et al., 2001). 
FPD is an important aspect related to birds' welfare (Abd El-Wahab et al., 2011, 2012a). The present data show significant effects of different protein sources (despite the almost identical chemical composition of the four diets) on the FPD scores. However, it has to be pointed out that the high FPD scores might be related to the high water consumption caused by the unintended high dietary electrolyte content (Na $\left.2.0 \mathrm{~g} \cdot \mathrm{kg}^{-1} \mathrm{DM}, \mathrm{K} 8.9 \mathrm{~g} \cdot \mathrm{kg}^{-1} \mathrm{DM}\right)$ and its effect on litter quality. The poorer results in the group RSM were unexpected, contrary to previous findings of Kölln et al. (2014) who found that replacing SBM with RSM up to $20 \%$ led to significantly lower FPD in broilers. These positive effects on foot pad health might be related to the reduced intake of stachyose, verbascose and raffinose (sticky excreta) by reducing the amount of SBM in the diets and consequently in the favourable DM contents of the litter (Kölln et al., 2014). In another study, different levels of dietary RSM up to $180 \mathrm{~g} \cdot \mathrm{kg}^{-1}$ diet had no significant effect on the severity of FPD in turkeys reared for 21 weeks (Mikulski et al., 2012).

\section{Conclusions}

Rapeseed meal could be the most suitable alternative protein source for broilers due to higher body weight gains. However, further studies are required to lower its effect on foot pad health. Although haemoglobin meal was the richest in protein, it is not recommended to use it more than $4 \%$ in the broiler diet. Feeding algae meal led to a comparable body weight gain to soyabean meal but its price might limit its use in poultry diets in addition to its adverse effects on foot pad health.

\section{References}

Abd El-Wahab A., Beineke A., Beyerbach M., Visscher C.F., Kamphues J., 2011. Effects of floor heating and litter quality on the development and severity of foot-pad dermatitis in young turkeys. Avian Dis. 55, 429-434, https://doi. org/10.1637/9684-021011-Reg.1

Abd El-Wahab A., Visscher C.F., Beineke A., Beyerbach M., Kamphues J., 2012a. Experimental studies on the effects of different litter moisture contents and exposure time to wet litter on development and severity of foot pad dermatitis in young fattening turkeys. Arch. Geflugelkd. 76, 55-62

Abd El-Wahab A., Visscher C.F., Wolken S., Reperant J.-M., Beineke A., Beyerbach M., Kamphues J., 2012b. Foot-pad dermatitis and experimentally induced coccidiosis in young turkeys fed a diet without anticoccidia. Poult. Sci. 91, 627635, https://doi.org/10.3382/ps.2011-01840
Abd El-Wahab A., Visscher C.F., Beineke A., Beyerbach M., Kamphues J., 2013a. Effects of high electrolyte contents in the diet and using floor heating on development and severity of foot pad dermatitis in young turkeys. J. Anim. Physiol. Anim. Nutr. 97, 39-47, https://doi.org/10.1111/j.1439-0396.2011.01240.x

Abd El-Wahab A., Visscher C.F., Wolken S., Reperant L.-M., Beineke A., Beyerbach M., Kamphues J., 2013b. Outcome of an artificial coccidial infection in poults under the influence of floor heating. Poult. Sci. 92, 629-637, https://doi.org/10.3382/ ps.2012-02614

Becker W., 2004. Microalgae in human and animal nutrition. In: A. Richmond (Editor). Handbook of Microalgal Culture: Biotechnology and Applied Phycology. Blackwell Publishing Ltd. Hoboken, NJ (USA), pp. 312-351, https://doi. org/10.1002/9780470995280.ch18

Becker E.W., 2007. Micro-algae as a source of protein. Biotechnol. Adv. 25, 207-210, https://doi.org/10.1016/j.biotechadv.2006.11.002

Beski S.S.M., Swick R.A., lji P.A., 2015. Specialized protein products in broiler chicken nutrition: a review. Anim. Nutr. 1, 47-53, https://doi.org/10.1016/j.aninu.2015.05.005

Choct M., 1997. Enzymes in animal nutrition: the unseen benefits. In: R.R. Marquardt, Z. Han (Editors). Enzyme in Poultry and Swine Nutrition. International Development Research Centre. Ottawa (Canada), pp. 45-51

Choct M., Dersjant-Li Y., McLeish J., Peisker M., 2010. Soy oligosaccharides and soluble non-starch polysaccharides: a review of digestion, nutritive and anti-nutritive effects in pigs and poultry. Asian-Australas. J. Anim. Sci. 23, 1386-1398, https://doi. org/10.5713/ajas.2010.90222

Clandinin D.R., 1967. Nutrient composition of expeller, prepress-solvent and solvent processed rapeseed meals. Poult. Sci. 46, 1596-1597, https://doi.org/10.3382/ps.0461596

Donkoh A., Anang D.M., Atuahene C.C., Koomson B., Oppong H.G., 2001. Further studies on the use of solar-dried blood meal as a feed ingredient for poultry. J. Anim. Feed. Sci. 10, 159-167, https://doi.org/10.22358/jafs/67953/2001

Ekstrand C., Algers B., Svedberg J., 1997. Rearing conditions and footpad dermatitis in Swedish broiler chickens. Prev. Vet. Med. 31, 167-174, https://doi.org/10.1016/S0167-5877(96)01145-2

Evans A.M., Smith D.L., Moritz J.S., 2015. Effects of algae incorporation into broiler starter diet formulations on nutrient digestibility and 3 to $21 \mathrm{~d}$ bird performance. J. Appl. Poult. Res. 24, 206-214, https://doi.org/10.3382/japr/pfv027

FAO, 2013. Dietary Protein Quality Evaluation in Human Nutrition. Report of an FAO Expert Consultation. FAO Food and Nutrition Paper 92. Food and Agriculture Organization of the United Nations, Rome (Italy)

FAO, 2016. FAOSTAT. Food and Agriculture Organization of the United Nations, Rome (Italy), http://www.fao.org/faostat/

Kamphues J., Youssef I., Abd El-Wahab A., Üffing B., Witte M., Tost M., 2011. Influences of feeding and housing on foot pad health in hens and turkeys (in German). Übers. Tierernähr. 39, 147-193

Kermanshahi H., Abbasi Pour A.R., 2006. Replacement value of soybean meal with rapeseed meal supplemented with or without a dietary NSP-degrading enzyme on performance, carcass traits, and thyroid hormones of broiler chickens. Int. J. Poult. Sci. 5, 932-937, https://doi.org/10.3923/ijps.2006.932.937

Khawaja T., Ansari N.N., Hassan Khan S., 2007. Effect of different levels of blood meal on broiler performance during two phases of growth. Int. J. Poult. Sci. 6, 860-865, https://doi.org/10.3923/ ijps.2007.860.865 
KocherA., Choct M., Porter M.D., Broz J., 2002. Effects of feed enzymes on nutritive value of soyabean meal fed to broilers. Br. Poult. Sci. 43, 54-63, https://doi.org/10.1080/00071660120109890

Kölln M., Köpping M., Kamphues J., 2014. Partial substituting soybean meal in broiler diets by rapeseed meal: performance, composition of the litter and foot pad health. Proc. Soc. Nutr. Physiol. 23, 91

Laudadio V., Tufarelli, V., 2011. Dehulled-micronised lupin (Lupinus albus $\mathrm{L}$. cv. Multitalia) as the main protein source for broilers: influence on growth performance, carcass traits and meat fatty acid composition. J. Sci. Food Agric. 91, 2081-2087, https:// doi.org/10.1002/jsfa.4426

March B.E., Biely J., 1971. An evaluation of the supplementary protein and metabolizable energy value of rapeseed meals for chicks. Can. J. Anim. Sci. 51, 749-756, https://doi.org/10.4141/ cjas71-101

Mayne R.K., Else R.W., Hocking P.M., 2007. High litter moisture alone is sufficient to cause footpad dermatitis in growing turkeys. Br. Poult. Sci. 48, 538-545, https://doi. org/10.1080/00071660701573045

Mikulski D., Jankowski J., Zdunczyk Z., Juskiewicz J., Slominski B.A., 2012. The effect of different dietary levels of rapeseed meal on growth performance, carcass traits, and meat quality in turkeys. Poult. Sci. 91, 215-223, https://doi.org/10.3382/ ps.2011-01587

Nagel F., Slawski H., Adem H., Tressel R.-P., Wysujack K., Schulz C., 2012. Albumin and globulin rapeseed protein fractions as fish meal alternative in diets fed to rainbow trout (Oncorhynchus mykiss W.). Aquaculture 354-355, 121-127, https://doi. org/10.1016/j.aquaculture.2012.03.024

Nahashon S.N., Adefope N., Amenyenu A., Wright D., 2006. Effect of varying metabolisable energy and crude protein concentrations in diets of pearl gray guinea fowl pullets 1 . Growth performance. Poult. Sci. 85, 1847-1854, https://doi.org/10.1093/ ps/85.10.1847

Pulz O., Gross W., 2004. Valuable products from biotechnology of microalgae. Appl. Microbiol. Biotechnol. 65, 635-648, https:// doi.org/10.1007/s00253-004-1647-x
Spolaore P., Joannis-Cassan C., Duran E., Isambert A., 2006. Commercial applications of microalgae. J. Biosci. Bioeng. 101, 87-96, https://doi.org/10.1263/jbb.101.87

Taherparvar G., Seidavi A., Asadpour L., Payan-Carreira R., Laudadio V., Tufarelli V., 2016. Effect of litter treatment on growth performance, intestinal development, and selected cecum microbiota in broiler chickens. Rev. Bras. Zootecn. 45, 257-264, https://doi.org/10.1590/S1806-92902016000500008

Toghyani M., Mohammedsalehi A., Gheisari A., Tabeidian S.A., 2009. The effect of low-glucosinolate rapeseed meal in diets with multi-enzyme supplement on performance and protein digestibility in broiler chicks. J. Anim. Feed Sci. 18, 313-321, https:// doi.org/10.22358/jafs/66396/2009

Tufarelli V., Dario M., Laudadio V., 2007. Effect of xylanase supplementation and particle-size on performance of guinea fowl broilers fed wheat-based diets. Int. J. Poult. Sci. 4, 302-307, https://doi.org/10.3923/ijps.2007.302.307

van der Spiegel M., Noordam M.Y., van der Fels-Klerx H.J., 2013. Safety of novel protein sources (insects, microalgae, seaweed, duckweed, and rapeseed) and legislative aspects for their application in food and feed production. Compr. Rev. Food Sci. Food Saf. 12, 662-678, https://doi.org/10.1111/15414337.12032

VDLUFA, 2012. VDLUFA Method Book. Volume III - The Chemical Analysis of Feed. $8^{\text {th }}$ Supplement (in German). VDLUFAVerlag, Darmstadt (Germany)

Yaakob Z., Ali E., Zainal A., Mohamed M., Takriff M.S., 2014. An overview: biomolecules from microalgae for animal feed and aquaculture. J. Biol. Res. (Thessalon) 21, 6, https://doi. org/10.1186/2241-5793-21-6

Youssef I.M.I., Beineke A., Rohn K., Kamphues J., 2011. Effects of high dietary levels of soybean meal and its constituents (potassium, oligosaccharides) on foot pad dermatitis in growing turkeys housed on dry and wet litter. Arch. Anim. Nutr. 65, 148-162, https://doi.org/10.1080/1745039X.2010.533548

Zeb A., 1998. Possibilities and limitations of feeding rapeseed meal to broiler chicks. Ph.D. Thesis. Georg August University of Göttingen, Göttingen (Germany) 